International Journal of Linguistics, Literature and Culture
Available online at https://sloap.org/journals/index.php/ijllc/
Vol. 6, No. 4, July 2020, pages: 103-114
ISSN: 2455-8028
https://doi.org/10.21744/ijllc.v6n4.911

\title{
Strategies of Conveying Metaphors in Political Discourse: Analysis of the Turkish Translations of George Orwell's "Animal Farm"
}

Iryna Sekret a

Article history:

Submitted: 18 April 2020

Accepted: 09 May 2020

\section{Keywords:}

“Animal Farm” by George

Orwell;

comparative analysis;

English-Turkish translation;

metaphor;

political discourse;

text deformation;

translation shifts;

translation;

\begin{abstract}
Translating metaphor and metaphoric expressions is one of the disputable problems in translation studies due to the conceptual discrepancies which exist between the source culture and the target readership, moreover, if the metaphor plays a crucial role in creating an appeal to the reader as in the political text. In this respect, it is under the discussion of how to deal with a metaphor when translating political discourse, and what are the dominating strategies and traditions of translating metaphoric units in Turkish translations. Caused by the theoretical and practical urgency of the problem, this paper is aimed to analyze strategies of conveying metaphors from English to Turkish based on the novel "Animal Farm" by George Orwell and its Turkish translations by Sedat Demir and Celal Üster. To achieve the aims of the research the efforts were undertaken to compare the original text with its two different translations. For the precise analysis, Old Major's speech was thoroughly scrutinized on the point of the metaphoric expressions in the text and their correspondences in the Turkish translations. The methods applied in the research include the discourse analysis aimed to re-veal metaphors in the source text, comparative analysis to identify language items used in the translations to convey the metaphors, and methods of the structural analysis for contrasting lexical constructions in the source text and its translations, analysis of the translation shifts. The conclusions outline strategies applied for translating metaphoric expressions from English into Turkish with the identifications of the shifts which occur in the texts of translation.
\end{abstract}

International journal of linguistics, literature and culture $\odot 2020$. This is an open access article under the CC BY-NC-ND license. Peer-review under responsibility of International Association for Technology, Education and Language Studies (IATELS) (https://creativecommons.org/licenses/by-nc-nd/4.0/).

\section{Corresponding author:}

Iryna Sekret,

Startin Forum International, Turkey

IATELS International Association for Technology, Education and Language Studies.

Email address: irenesekret@gmail.com

${ }^{a}$ Startin Forum International, Turkey, IATELS International Association for Technology, Education and Language Studies 


\section{Introduction}

Due to the intensive development of the translation studies dealing with the problems of transferring different aspects of discourse from one language to another, it is essential to conduct descriptive research on the translator's behaviors and strategies aimed to bring ST literature to the TL readers' better understanding and appreciation.

Considering the theoretical and practical value of such interventions in the analysis of translation, a big number of the studies have been conducted so far, concerning the problems of culture in translation (Yan \&Huang, 2014), analysis of the text at the pre-translation stage (Ayupova, 2014), the personality of the translator (Chesterman, 2009; Dam, 2013); translation strategies (Strakšiene, 2009; Volkova, 2014); translation evaluation (Conde, 2011), etc. The focus of the current study is on the strategies applied to translate metaphoric expressions from English into Turkish on the base of George Orwell's "Animal Farm” (Orwell, 1988).

The novel and the problems of its translation is the topic which was discussed in many studies. Among them are those which focus on social and political issues of the translation (Yazıc1, 2012), assessing the quality of translation on the equivalency of the speeches in English - Azerbaijani Turkish translation (Bahloul \& Salmani, 2014), contrastive analysis at the lexical and structural level (Abbasi \&Arjenan, 2014).

Because this novel has been already translated into the Turkish language several times starting from its first translation by Halide Edib Adivar in 1954 (Orwell, 1954/1966; Yazıc1, 2012) and including its later versions by Sedat Demir (2001), Celal Üster (Orwell, 2011), the study is aimed to conduct a comparative analysis of the translators' strategies in conveying metaphoric expressions from English into Turkish.

\section{Literature Review}

\subsection{Problems of Translating George Orwell's “Animal Farm”: Analysis of the Recent Case Studies}

While conducting the literature review we focus on the studies devoted to the problems of translating George Orwell's "Animal Farm", and on those concerning metaphor in the discourse and practices of its translation.

As far as the novel "Animal Farm" by George Orwell is the book that has already firmly established itself among classics of the political prose and has been numerously translated in different languages, therefore, within our concern was to identify translation problems which were discussed by researchers. A possibility to contrast results with the researchers from different languages can allow us to find out unified approaches in translation and also to specify those which are caused by the peculiarities of the language of translation, translation practices, and dominating strategies within different societal groups.

The studies concerning the translation of "Animal Farm" by George Orwell circle around a big number of issues. Thus, following traditions of the system theories in translation, Yazıc1 (2012) discusses sociological and political issues of the first translation of the book into Turkish by Halide Edib, stressing the correlation between the personality of the author and the translator. Also, an important remark is made on the metrical elements in the source text and its translation, indicating that in Halide Edip's version, the novel was not divided into chapters because of the traditions of the Turkish literary polysystem not to divide legends and fairy tales into sections. Due to Yazic1 (2012), Edip managed to seize the plain style of Orwell as a translator, by applying the high number of binomials, near-synonyms, and idiomatic expressions in the translation process.

In the context of the theories, discussing translation from the perspectives of the political power and ideology Khorsand \& Salmani (2014) scrutinizes English - Azerbaijani Turkish translation of Squealer's speech from Orwell's Animal Farm based on House's revised translation quality assessment (TQA) model. The conclusions of the study reflect on enormous ideological distortions and manipulation which were carried out in the translation. Therefore, Khorsand \& Salmani state that the translation is covert, and the social effect received by the source and target texts' readerships would be radically different from each other (Khorsand \& Salmani, 2014). The findings are based on the identified discrepancies between lexical means of ST and TT, syntactic structures, mismatches between denotative meanings of ST and TT elements.

The research by Askari \& Akbari (2014) studies the problems of rendering English proper names of the novel in the Persian translations. The strategies of foreignization and domestications were traced in the translation of proper names. It states that the function is a determining factor in translation, therefore, the strategies the translators apply to meet the requirements of the function can differ considerably. According to the findings of Askari \& Akbari, one of the most common strategies renderers use when translating proper names is transference. The transferred items are 
accompanied by the English versions in parenthesis as a kind of compensation strategy. But, as Askari \&Akbari notes, adding or deleting the intended parenthesis makes no difference for the reader since a foreign word for the reader remains to be foreign (Askari \& Akbari, 2014).

Another study evaluating the translation from propaganda is the research conducted by Khorsand \& Salmani (2014) and aimed to assess the quality of two English-Persian translations of the anthems in Orwell's Animal Farm (1945) based on House's (1997/2009) revised discoursal model (Khorsand \& Salmani, 2014). The study discusses techniques and strategies that are applied to propaganda as follows: (a) Selected facts in support and confirmation of an idea or statement; (b) Lying and purposefully deceiving through an intentionally untruthful statement; (c) Repetition, that is, to retell the same words repeatedly to be imprinted on the people's mind forever. (d) Identifying the (true or false) enemy, that is, to diverting the public opinion and attention into an imaginary enemy away from the speaker (e) Rhetorical questions (intend-ing not to encourage a specific answer, but rather to elicit the listener to regard a message or perspective) (f) Contention (a strong opinion that someone expresses, that is, bold statements) (Khorsand \& Salmani, 2014). Salman provides a thorough analysis of the anthems as instruments of propaganda in the book. While contrasting the translations, the researcher identifies distortions at the level of words and sentence structures as the result of omissions/transformations which can be interpreted as ideological and become a reason for misunderstanding and misinterpretation of the message of the source text (Khorsand \& Salmani, 2014).

Together with the studies, contrasting translations with the original text at the microlevel and considering their ideological and functional attributes, a bulk of research analyzing translations at the microlevel has been conducted, that is the lexical adjustment in the Persian translations (Azizmohammadi \& Saadatmanesh, 2013), rendering speech acts (Rad \& Razmjou, 2013), and many others.

One of the studies which go alongside with this research is the investigation conducted by Elaheh Fadaee (2011) on the strategies of conveying figurative linguistic means of George Orwell's "Animal Farm" in the Persian translation. The study analyses translation strategies for dealing with a metaphor-based on the approach suggested by Newmark (1988b). The researcher attempts to trace prevailing techniques in the Persian translations for conveying metaphors, pointing to the considerable statistical differences in the usage of metaphoric expressions in different translations (Fadaee, 2011). To proceed with the investigation of the problem we will focus on the exact subject of our study, namely, metaphor, its definition, and classification to apply the theoretical assumptions to analyze the Turkish translations.

\subsection{Metaphor in the Discourse: Problems of Definition and Classification}

As it is known, the essence of metaphor is understanding and experiencing one kind of thing or experience in terms of another (Lakoff \& Johnson, 1980). Torgny (1997) stat-ed that the first known theory on metaphors was presented by Aristotle, who saw metaphor as a rhetorical phenomenon by using one concept, or word, to indicate another.

According to Lakoff (1987), two kinds of metaphors can be identified: basic metaphors and image metaphors, where the basic metaphors form basic concepts from which some image metaphors are generated (Torgny, 1997). The power of metaphor is in activating previous experiences and associations (Black 1979, Torgny, 1997).

Despite a great number of studies the problem of defining metaphor, differentiating it from other figures of speech, identifying it in the discourse remains to be disputable, moreover when it concerns the translation and analysis of how metaphoric expressions are conveyed with the means of the TL. The lack of research in this area was stressed in numerous studies, among them Newmark (1988), Taverniers (2002), Al-Hasnawi (2007), Shaman (2008), Fadaee (2011). The outlined problem also became a focus of the research by Elaheh Fadaee (2011), who studies the strategies of conveying figurative linguistic means of George Orwell's "Animal Farm" in the Persian translation.

To conduct this study we are following Newmark's classification of metaphors (New-mark, 1988b):

1) Dead Metaphors - "metaphors which often relate to universal terms of time and space, general ecological features and main human activities" (p.106). They include idioms, metonyms, synecdoche; words accepted as technical terms also become dead metaphors.

2) Cliché - metaphors "used as a substitute for clear thought, often emotively, but with-out corresponding to the facts of the matter" (1988b, p.107). They "usually consist of two types of collocations: figurative adjective and literal noun e.g. 'filthy lucre'; or figurative verb and figurative noun e.g. "explore all avenues"” (1988, p.87).

3) Stock Metaphors - "an established metaphor, which is an informal context is an efficient and concise method

Sekret, I. (2020). Strategies of conveying metaphors in political discourse: analysis of the Turkish translations of George Orwell's “Animal Farm”. International Journal of Linguistics, Literature and Culture, 6(4), $103-114$. https://doi.org/10.21744/ijllc.v6n4.911 
of covering a physical and/or mental situation both referentially and pragmatically".

4) Adapted Metaphors - stock metaphors adapted by the writer or speaker into a new context.

5) Recent Metaphors - "a metaphorical neologism, often 'anonymously' coined, which has spread rapidly in the SL", often categorized as a slang.

6) Original Metaphors - "created or quoted by the SL writer" (Newmark, 1988b). These metaphors can be complex and having double meanings.

\section{Materials and Methods}

The methods applied in the study include:

1) The discourse analysis aimed to reveal metaphors in the source text and translated texts,

2) Comparative analysis to identify language items used in the translations to convey the metaphors,

3) Methods of the structural analysis for contrasting lexical constructions in the source text and its translations;

4) Analysis of the translation shifts in TT.

For the precise analysis, Old Major's speech (Chapter 1) was thoroughly scrutinized on the metaphoric expressions in the text and their correspondences in the Turkish translations. The decision to focus on Old Major's speech for the contrastive analysis is motivated by the considerations that a) Old Major is a leading character in the story, and b) the speech of Old Major represents all features of the propaganda texts which were mentioned above. Thus, as it was noted by Khorsand \& Salmani (2014b) Old Major is an award-winning boar, who holds a meeting consisting of the animals of the Manor Farm in the big barn. Following Khorsand \& Salmani in their reference to SparkNotes (2007), Major "represents both Marx and Lenin, serves as the source of the ideals that the animals continue to uphold even after their pig leaders have betrayed them" (SparkNotes, 2007).

\section{Results: Analysis of Metaphors and Strategies of their Translation}

The study is primarily concerned with the main ways and techniques applied by the Turkish translators to render metaphorical expressions of Old Major's speech from English to Turkish. In this way, it is intended to highlight the metaphor translation procedures applied by two translators Celal Üster and Sedat Demir with the special focus on the translation shifts and textual deformation tendencies occurred (for the translation notifications and contrasting Celal Üster's translation is marked as TT1, and Sedat Demir's translation as TT2).

Before entering the analysis it is important to consider specifics of the writing style of the author for discussing correspondence of the translations to the author's style and character's features. It is worth noting that Orwell uses many different writing tools but one, in particular, is plain language. Orwell's straightforward language use is obvious in his satirical novel Animal Farm (1945). The author uses a simple style of writing and thus, avoids sophisticated language. Advocating plain language in his 1946 essay, Orwell offers elementary rules for writers: "Never use a long word where a short one will do. In the wrong situation, they'll have the opposite effect, making you sound pretentious and arrogant. They're also less likely to be understood and more awkward to read." Old Major's addressee where the well-respected boar of the farm gives a tempting political speech to the community is a good example of the plain language of Orwell. Yet, in the plain speech of Old Major, there are the metaphoric expressions which are analyzed as follows.

In the context scrutinized, the first ST metaphor to start to analyze with is the unit 'to-wards Man and all his ways'. The first part of the unit is rendered similar in both of the translations. As the cognitive mechanism of the metaphor 'Man' does not require linguistic or cultural adaptation, it was translated on a word-for-word basis. However, the dead metaphor 'all his ways' was found to be interpreted differently by both translators. Namely, in the TT1, the first translator broadens the semantic meaning of 'all his ways' and accordingly produces a TL equivalent that metrically occupies a larger place than that of SL. The TT1 whose rendering of the ST metaphor 'all his ways' runs like 'onun başının altından çıkan tüm uğursuzluklara karşı (Back Tr. all the in the inauspiciousness that is His' doing)' commits two textual deformation tendencies which are expansion and ennoblement. In this way, TT1 becomes longer than ST and the oral rhetoric of the ST is destructed by TT1. This additional fancy prose implemented by the first translator turns Old Major to sound more clever and arrogant than he really is. Implementing complexity and violating simplicity, TT1 in this way can betray the spirit of the foreign and the 
author's writing style.

In TT2 the same ST metaphor 'all his ways' is rendered as 'yaptıklarına (Back Tr. against what He has done)', using simple grammatical and lexical means. The one-word ST lexical unit 'ways' is transferred by one-word TT lexical unit 'yaptıklarına (Back Tr. what He has done)', revealing no textual deformations. Consequently, considering the author's preference for the transparency and simplicity of the TT form, TT2 reveals the closeness of the TT2 to the ST in the oratory style, and, therefore, fidelity to the spirit of the foreign (Table 1).

Table 1

Comparative analysis of metaphor translations in TT1 and TT2

\begin{tabular}{|l|l|l|l|l|l|l|l|}
\hline $\begin{array}{l}\text { ST } \\
\text { Metaphor }\end{array}$ & $\begin{array}{l}\text { ST } \\
\text { Metaphor } \\
\text { Type }\end{array}$ & TT1 & $\begin{array}{l}\text { Back- } \\
\text { translation }\end{array}$ & $\begin{array}{l}\text { Translation } \\
\text { Procedure }\end{array}$ & TT2 & $\begin{array}{l}\text { Back- } \\
\text { translatio } \\
\mathrm{n}\end{array}$ & $\begin{array}{l}\text { Translation } \\
\text { Procedure }\end{array}$ \\
\hline $\begin{array}{l}\text { "towards } \\
\text { all his } \\
\text { ways". }\end{array}$ & $\begin{array}{l}\text { Dead } \\
\text { metaphor }\end{array}$ & $\begin{array}{l}\text { İnsan'a ve } \\
\text { onun başının } \\
\text { altından } \\
\text { ç1kan tüm } \\
\text { uğursuzlukla } \\
\text { ra karş1 }\end{array}$ & $\begin{array}{l}\text { against Man } \\
\text { and in all the } \\
\text { inauspiciousn } \\
\text { ess that is } \\
\text { His' doing }\end{array}$ & $\begin{array}{l}\text { Converting of } \\
\text { metaphor to sense } \\
\text { Replacing the } \\
\text { image in the SL } \\
\text { with a standard TL } \\
\text { image which does } \\
\text { not clash with the } \\
\text { TL culture }\end{array}$ & $\begin{array}{l}\text { insanlara ve } \\
\text { yaptiklarına } \\
\text { karş1 }\end{array}$ & $\begin{array}{l}\text { Manst and } \\
\text { what he } \\
\text { has done }\end{array}$ & $\begin{array}{l}\text { Converting } \\
\text { of metaphor } \\
\text { to sense }\end{array}$ \\
\hline
\end{tabular}

\begin{tabular}{|l|l|}
\hline TT1 Translation Shift & TT2 Translation Shift \\
\hline Class shift, unit shift, lexical modulation & Lexical modulation, level shift \\
\hline
\end{tabular}

Another example under the analysis is the lexis 'laborious' in the sentence '...our lives miserable, laborious, and short'. The dictionary defines the word 'laborious' as 'involving or characterized by hard or toilsome effort' (Merriam-Webster, Digital Dictionary). In TT1 translation it is presented as 'sabahtan akşama kadar uğraşıp didinmek (Back Tr. toiling and moiling from morning till night)' (Table 2). One ST word was rendered into the extended metaphoric expression. The TT1 counterpart of the word 'laborious' was replaced culturally dependent expression 'sabahtan akşama kadar uğraşıp didinmek', deforming the metrics of the text. The translator replaces the SL word with a more elegant TL metaphoric counterpart and thus, enhances the simple way of writing. Therefore, the perceptional image transferred through the SL is rendered in the TT1, though significantly exaggerating the impact upon the recipients. From this point of view, the TT1 demonstrates 'ennoblement' as the 'textual deformation' in terms of Berman's theory about the deformation tendencies in translation (Munday, 2008).

The translation of the word 'laborious' in the TT2, however, was interpreted using another metaphoric expression 'hiç durmadan çalışmak (Back Tr. working without any stops)'. The TT2 also demonstrates ennoblement and metrical distortion through its emotional impact upon the recipient's approaches to the original text.

As for the ST metaphors 'miserable and short', their meanings were preserved in both the TT1 (Tr. kölelik, Back Tr. poverty; Tr. kısa, Back Tr. short) and the TT2 (Tr. se-falet, Back Tr. wretchedness; Tr. k1sa, Back Tr. short). The TT translators conveyed the above-mentioned ST metaphors maintaining the balance in terms of style and length of the expressions (Table 2).

Sekret, I. (2020). Strategies of conveying metaphors in political discourse: analysis of the Turkish translations of George Orwell's “Animal Farm”. International Journal of Linguistics, Literature and Culture, 6(4), $103-114$. https://doi.org/10.21744/ijllc.v6n4.911 
Table 2

Comparative Analysis of Metaphor Translations in TT1 and TT2

\begin{tabular}{|c|c|c|c|c|c|c|c|}
\hline $\begin{array}{l}\text { ST } \\
\text { Metaphor }\end{array}$ & $\begin{array}{l}\text { ST } \\
\text { Metaphor } \\
\text { Type }\end{array}$ & TT1 & $\begin{array}{l}\text { Back- } \\
\text { translation }\end{array}$ & $\begin{array}{l}\text { Translation } \\
\text { Procedure }\end{array}$ & TT2 & $\begin{array}{l}\text { Back- } \\
\text { translation }\end{array}$ & $\begin{array}{l}\text { Translatio } \\
\mathrm{n} \\
\text { Procedure }\end{array}$ \\
\hline $\begin{array}{l}\text { "'[...]our } \\
\text { lives } \\
\text { miserable, } \\
\text { laborious, } \\
\text { and short", }\end{array}$ & $\begin{array}{l}\text { Stock } \\
\text { metaphor }\end{array}$ & $\begin{array}{l}\text { ‘'Şu kisa } \\
\text { ömrümüz } \\
\text { yoksulluk } \\
\text { içinde, sabahtan } \\
\text { akşama kadar } \\
\text { uğraşıp } \\
\text { didinmekle } \\
\text { geçip gidiyor. }\end{array}$ & $\begin{array}{l}\text { Our short } \\
\text { lives go by in } \\
\text { poverty, } \\
\text { toiling, and } \\
\text { moiling from } \\
\text { morning till } \\
\text { night. }\end{array}$ & $\begin{array}{l}\text { Replacing } \\
\text { the image in } \\
\text { the SL with } \\
\text { a TL } \\
\text { metaphor }\end{array}$ & $\begin{array}{l}\text { Kısa } \\
\text { hayatımız } \\
\text { sefalet } \\
\text { içinde ve } \\
\text { hiç } \\
\text { durmadan } \\
\text { çalışmakla } \\
\text { geçer. }\end{array}$ & $\begin{array}{l}\text { Our short } \\
\text { lives go by } \\
\text { in } \\
\text { wretchednes } \\
\text { s and } \\
\text { working } \\
\text { continually. }\end{array}$ & $\begin{array}{l}\text { Convertin } \\
\mathrm{g} \text { of } \\
\text { metaphor } \\
\text { to sense }\end{array}$ \\
\hline
\end{tabular}

\section{TT1 Translation Shift}

TT2 Translation Shift

Unit shift (2), class shift, non-obligatory structural Unit shift (2), class shift, non-obligatory structural shift shift

Another expression to bring to the discussion is the SL metaphor 'to work to the last atom of our strength' in the sentence ' [...] those of who are capable of it are forced to work to the last atom of our strength' (Table 3). In TT1 it was translated as 'canı çıkana kadar çalışmak' which means 'someone is forced to work so hard that his/her soul detaches from his/her body at the end of overwork'. In this case, the TT1 translator again uses the strategy which ennobles the text. In the second translation, however, the TT2 translator reproduces the original image in TL and interprets it as 'en ufak zerresine [ Back Tr. to the merest (1) piece (2)]'. The TT metaphor, used in TT2, tends to preserve simplicity of the form and meaning, though undergoing lexical modulations 'the last(1) atom (2)'.

From the grammatical structures both translators keep passiveness in the TT.

ST: ' $[\ldots]$ those of who are capable of it are forced to work [...]

TT1: 'ayakta kalanlarımızı canı çıkana kadar çalıştırırlar'" (Back Tr. '(They) work us to work') The sentence was reconstructed with a 'null subject'.

TT2: 'Gücü yetenlerimiz en ufak zerresine kadar çalışmaya zorlanırlar." (Back Tr. 'Those are forced[...]').

It also cannot stay unnoticed that the part 'those of who are capable' is translated differently by the Turkish translators, using metaphoric expressions that represent non-obligatory structural shifts. The application of metaphors as the replacement of the plain text of the origin consequently elevates the style of the TT and therefore, its emotional impact upon the audience (Table 3).

Table 3

Comparative Analysis of Metaphor Translations in TT1 and TT2

\begin{tabular}{|c|c|c|c|c|c|c|c|}
\hline ST Metaphor & $\begin{array}{l}\text { ST } \\
\text { Metaphor } \\
\text { Type }\end{array}$ & TT1 & $\begin{array}{l}\text { Back- } \\
\text { translation }\end{array}$ & $\begin{array}{l}\text { Translation } \\
\text { Procedure }\end{array}$ & TT2 & $\begin{array}{l}\text { Back- } \\
\text { translation }\end{array}$ & $\begin{array}{l}\text { Translation } \\
\text { Procedure }\end{array}$ \\
\hline $\begin{array}{l}\text { "[...]those of } \\
\text { who are } \\
\text { capable of it } \\
\text { are forced to } \\
\text { work to the } \\
\text { last atom of } \\
\text { our strength", }\end{array}$ & $\begin{array}{l}\text { Stock } \\
\text { metaphor } \\
\text { Original } \\
\text { metaphor }\end{array}$ & $\begin{array}{l}\text { ''ayakta } \\
\text { kalanları } \\
\text { mızı canı } \\
\text { çıkana } \\
\text { kadar } \\
\text { çalıştırırla } \\
\text { r', }\end{array}$ & $\begin{array}{l}\text { (They) have } \\
\text { those of } \\
\text { who are } \\
\text { survivors of } \\
\text { it work till } \\
\text { they get all } \\
\text { tuckered out }\end{array}$ & $\begin{array}{l}\text { Replacing the } \\
\text { image in the SL } \\
\text { with a standard } \\
\text { TL image which } \\
\text { does not clash } \\
\text { with the TL } \\
\text { culture }\end{array}$ & $\begin{array}{l}\text { “'Gücü } \\
\text { yetenlerimiz en } \\
\text { ufak zerresine } \\
\text { kadar } \\
\text { çalışmaya } \\
\text { zorlanırlar.", }\end{array}$ & $\begin{array}{l}\text { those of who } \\
\text { are strong } \\
\text { enough are } \\
\text { forced to } \\
\text { work to the } \\
\text { merest piece }\end{array}$ & $\begin{array}{l}\text { Reproducing } \\
\text { the same } \\
\text { image in TL }\end{array}$ \\
\hline
\end{tabular}




\begin{tabular}{|l|l|}
\hline TT1 Translation Shift & TT2 Translation Shift \\
\hline Unit shift & Structural shift, lexical modulation \\
\hline
\end{tabular}

Another sentence to analyze is 'Remove Man from the scene, and the root cause of hunger and overwork is abolished forever.' This sentence is a prominent example of propaganda speech using an abundance of images and metaphorical expressions (Table 4). The first one to mention is the appeal 'Remove Man', used in the imperative form, openly calling for actions. This SL metaphor was rendered in TT1 as 'insan'ı ortadan kaldırın (Back Tr. Take Man away from there)' and in TT2 as 'insanl[...]indirelim (Back Tr. Let's put down Man'). Although the linguistic transfer of the action verb 'remove' in one-word from English to Turkish is possible, the TT1 translator conveys the metaphor 'Remove' using a multi-word phrase 'ortadan kaldirmak (Back Tr. take away from there)' whereas the TT2 translator translates the metaphor with one-word verb (Tr. 'indirelim', Back Tr. put down) though modifying the lexical meaning and aspect. There is a noticeable difference in meaning between 'to remove' and 'to put down', which exemplifies the qualitative lexical modification. Simultaneously, the imperativeness of the original appeal is softened in TT2.

The second metaphorical image in the ST is 'from the scene'. The perceptual image of the ST metaphor was mapped onto 'the scene' which denotes the Earth on which human civilizations live. As can be seen from Table 4, the TT1 translator reproduces the original image through the metaphor (Tr. 'yeryüzünden, Back Tr. from the Earth), clarifying the implicit signified concept of the World. The TT2 translator, however, converts this ST metaphor into the sense (Tr. 'bulunduğu yerden', Back Tr. from the place He is present in), expanding the ST information whose meaning may be unclear in the TT context when translated.

The next metaphorical image in the analyzed sentence is 'the root cause'. While the TT1 translator reproduces the same image in TL, preserving the meaning of both 'root' and 'cause', the TT2 translator omits the ST metaphor 'the root' and transferring only the meaning of 'cause'. Deleting the metaphor 'the root', the TT2 translator inserts an 'embedded clause' (i.e. Tr. 'indirelim ki', Back Tr. we take Him down so that).

Another metaphor in the ST sentence is present with the item 'overwork'. The TT1 translator transfers its meaning with the metaphorical simile 'working like slaves', obviously deforming the text metrically and meaningfully. In TT2 the metaphor 'overwork' was translated as 'bitiviye çalışma(nın) (Back Tr. ceaseless working), reproducing structural shift and qualitative lexical modification.

Table 4

Comparative Analysis of Metaphor Translations in TT1 and TT2

\begin{tabular}{|c|c|c|c|c|c|c|c|}
\hline $\begin{array}{l}\text { ST } \\
\text { Metaphor }\end{array}$ & $\begin{array}{l}\text { ST } \\
\text { Metaphor } \\
\text { Type }\end{array}$ & TT1 & $\begin{array}{l}\text { Back- } \\
\text { translation }\end{array}$ & $\begin{array}{l}\text { Translation } \\
\text { Procedure }\end{array}$ & TT2 & $\begin{array}{l}\text { Back- } \\
\text { translation }\end{array}$ & $\begin{array}{l}\text { Translation } \\
\text { Procedure }\end{array}$ \\
\hline $\begin{array}{l}\text { 'Remove } \\
\text { Man from } \\
\text { the scene, } \\
\text { and the } \\
\text { root cause } \\
\text { of hunger } \\
\text { and } \\
\text { overwork } \\
\text { is } \\
\text { abolished } \\
\text { for ever.' }\end{array}$ & $\begin{array}{l}\text { Dead } \\
\text { metaphor } \\
\text { Stock } \\
\text { metaphor }\end{array}$ & $\begin{array}{l}\text { '"İnsan'ı } \\
\text { ortadan } \\
\text { kaldırın, } \\
\text { açlığın ve } \\
\text { köle gibi } \\
\text { çalışmanın } \\
\text { temelindeki } \\
\text { neden de } \\
\text { sonsuza dek } \\
\text { silinecektir } \\
\text { yeryüzünden } \\
\text {.," }\end{array}$ & $\begin{array}{l}\text { Take Man } \\
\text { away, the } \\
\text { underlying } \\
\text { reason of } \\
\text { hunger and } \\
\text { working like } \\
\text { slave will be } \\
\text { abolished } \\
\text { from the } \\
\text { earth for } \\
\text { ever. }\end{array}$ & $\begin{array}{l}\text { Translating } \\
\text { metaphor by } \\
\text { simile, } \\
\text { retaining the } \\
\text { image }\end{array}$ & $\begin{array}{l}{[\ldots] \text { insanı }} \\
\text { bulunduğu } \\
\text { yerden } \\
\text { indirelim; } \\
\text { indirelim ki } \\
\text { açlığın ve } \\
\text { biteviye } \\
\text { çalışmanın } \\
\text { sebebi } \\
\text { sonsuza kadar } \\
\text { yok olsun." }\end{array}$ & $\begin{array}{l}\text { Let's put } \\
\text { down Man } \\
\text { from the place } \\
\text { He is present } \\
\text { in; we take } \\
\text { Him down so } \\
\text { that the } \\
\text { reason of } \\
\text { hunger and } \\
\text { ceaseless } \\
\text { working will } \\
\text { be removed } \\
\text { for ever. }\end{array}$ & $\begin{array}{l}\text { Using the } \\
\text { same } \\
\text { metaphor } \\
\text { combined } \\
\text { with sense, in } \\
\text { order to } \\
\text { enforce the } \\
\text { image } \\
\text { Deletion, if } \\
\text { the metaphor } \\
\text { is redundant }\end{array}$ \\
\hline
\end{tabular}

Sekret, I. (2020). Strategies of conveying metaphors in political discourse: analysis of the Turkish translations of George Orwell's “Animal Farm”. International Journal of Linguistics, Literature and Culture, 6(4), 103-114. https://doi.org/10.21744/ijllc.v6n4.911 
110 Special Issue in International Association for Technology, Education and Language Studies (IATELS)

\begin{tabular}{|l|l|}
\hline TT1 Translation Shift & TT2 Translation Shift \\
\hline $\begin{array}{l}\text { Non- obligatory unit shift(2), Class shift, Structural shift, lexical } \\
\text { modification, replacement of images }\end{array}$ & $\begin{array}{l}\text { Non-obligatory unit shift(2), structural shift, } \\
\text { lexical modification }\end{array}$ \\
\hline
\end{tabular}

More examples of the metaphors from the analysed text and their Turkish translations can be found in Table 5 .

Table 5

Comparative Analysis of Metaphor Translations in TT1 and TT2

\begin{tabular}{|l|l|l|l|l|l|l|l|}
\hline $\begin{array}{l}\text { ST } \\
\text { Metaphor }\end{array}$ & $\begin{array}{l}\text { ST } \\
\text { Metaphor } \\
\text { Type }\end{array}$ & TT1 & $\begin{array}{l}\text { Back- } \\
\text { translation }\end{array}$ & $\begin{array}{l}\text { Translation } \\
\text { Procedure }\end{array}$ & TT2 & $\begin{array}{l}\text { Back- } \\
\text { translation }\end{array}$ & $\begin{array}{l}\text { Translation } \\
\text { Procedure }\end{array}$ \\
\hline $\begin{array}{l}\text { "the cruel } \\
\text { knife" }\end{array}$ & $\begin{array}{l}\text { Cliché } \\
\text { Metaphor }\end{array}$ & $\begin{array}{l}\text { gaddar } \\
\text { bıçakt } \\
\text { an }\end{array}$ & $\begin{array}{l}\text { the grim } \\
\text { knife }\end{array}$ & $\begin{array}{l}\text { Reproducing } \\
\text { the same image } \\
\text { in the TL }\end{array}$ & $\begin{array}{l}\text { zalim } \\
\text { bıçakt } \\
\text { an }\end{array}$ & $\begin{array}{l}\text { the brutal } \\
\text { knife }\end{array}$ & $\begin{array}{l}\text { Reproducing the } \\
\text { same image in the } \\
\text { TL }\end{array}$ \\
\hline
\end{tabular}

TT1 Translation Shift: Lexical modulation

TT2 Translation Shift: Lexical modulation

\begin{tabular}{|c|c|c|c|c|c|c|c|}
\hline $\begin{array}{l}\text { "'[...]we } \\
\text { are given } \\
\text { so much } \\
\text { food as } \\
\text { will keep } \\
\text { the breath } \\
\text { in our } \\
\text { bodies", }\end{array}$ & $\begin{array}{l}\quad \text { Stoc } \\
k \\
\text { metapho } \\
r\end{array}$ & $\begin{array}{l}\text { "...yaşa } \\
\text { mimıza } \\
\text { yetecek } \\
\text { kadar } \\
\text { yiyecek } \\
\text { verirler[ } \\
\ldots . \text {..' }\end{array}$ & $\begin{array}{l}\text { They } \\
\text { give as } \\
\text { much } \\
\text { food as to } \\
\text { be } \\
\text { enough to } \\
\text { live our } \\
\text { lives }\end{array}$ & \begin{tabular}{l}
\multicolumn{2}{c}{ Converting } \\
metaphor to \\
sense
\end{tabular} & $\begin{array}{l}\text { '...can } \\
\text { lı } \\
\text { kalabile } \\
\text { ceğimiz } \\
\text { kadar } \\
\text { yemek } \\
\text { verilir.' }\end{array}$ & $\begin{array}{l}\text { We are } \\
\text { given as } \\
\text { much food } \\
\text { as to be } \\
\text { able to } \\
\text { survive }\end{array}$ & $\begin{array}{c}\text { Converting } \\
\text { metaphor to sense }\end{array}$ \\
\hline
\end{tabular}

TT1 Translation Shift: Class shift, replacement of the symbol

TT2 Translation Shift: Class shift, replacement of the symbol

\begin{tabular}{|l|l|l|l|l|l|l|l|}
\hline $\begin{array}{l}\text {..that is } \\
\text { the plain } \\
\text { truth... }\end{array}$ & $\begin{array}{l}\text { Cliché } \\
\text { metaphor }\end{array}$ & $\begin{array}{l}\text { İşte, tüm } \\
\text { çılaklığılyl } \\
\text { a gerçek } \\
\text { budur. }\end{array}$ & $\begin{array}{l}\text { Here, this is } \\
\text { the truth with } \\
\text { all its } \\
\text { nakedness. }\end{array}$ & $\begin{array}{l}\text { TT } \\
\text { metaphor } \\
\text { enhanced } \\
\text { with } \\
\text { specificati } \\
\text { on }\end{array}$ & $\begin{array}{l}\text { Meselemiz bu } \\
\text { kadar açıktır }\end{array}$ & $\begin{array}{l}\text { Our } \\
\text { matter is } \\
\text { this much } \\
\text { clear }\end{array}$ & $\begin{array}{l}\text { Explaining } \\
\text { the meaning, } \\
\text { metaphor } \\
\text { omitted }\end{array}$ \\
\hline
\end{tabular}

TT1 Translation Shift: Optional structural shift, lexical modulation, specification
TT2 Translation Shift: Optional structural shift, sense explanation

\begin{tabular}{|l|l|l|l|l|l|l|l|}
\hline $\begin{array}{l}\text { 'The life } \\
\text { of an } \\
\text { animal is } \\
\text { misery and } \\
\text { slavery." }\end{array}$ & $\begin{array}{l}\text { Original } \\
\text { metaphor }\end{array}$ & $\begin{array}{l}\text { Hayatımız } \\
\text { sefillikten, } \\
\text { kölelikten } \\
\text { başka } \\
\text { nedir ki! }\end{array}$ & $\begin{array}{l}\text { Aren't our } \\
\text { lives } \\
\text { anything } \\
\text { else but } \\
\text { misery and } \\
\text { slavery! }\end{array}$ & $\begin{array}{l}\text { Emotional } \\
\text { impact raised } \\
\text { with the } \\
\text { emphatic } \\
\text { grammatical } \\
\text { structure }\end{array}$ & $\begin{array}{l}\text { Hayvanları } \\
\text { n hayat1, } \\
\text { sefalet ve } \\
\text { köleliktir. }\end{array}$ & $\begin{array}{l}\text { The life of } \\
\text { animals are } \\
\text { misery and } \\
\text { slavery. }\end{array}$ & $\begin{array}{l}\text { Reproduci } \\
\text { ng the } \\
\text { same } \\
\text { image in } \\
\text { the TL }\end{array}$ \\
\hline
\end{tabular}


TT1 Translation Shift: Non-obligatory intra-system shift, multiple structural shifts

TT2 Translation Shift: Obligatory intra-system shifts

\begin{tabular}{|c|c|c|c|c|c|c|c|}
\hline $\begin{array}{l}{[\ldots] \text { every }} \\
\text { one of you } \\
\text { will scream } \\
\text { your lives at } \\
\text { the block } \\
\text { within a year }\end{array}$ & $\begin{array}{l}\text { Adapted } \\
\text { metaphor }\end{array}$ & $\begin{array}{l}{[\ldots] \text { bir }} \\
\text { yıla } \\
\text { kalmaz, } \\
\text { bıçağın } \\
\text { altında } \\
\text { ciyaklaya } \\
\text { ciyaklaya } \\
\text { can } \\
\text { verirsiniz }\end{array}$ & $\begin{array}{l}{[\ldots] \text { a year }} \\
\text { or so, you } \\
\text { will die } \\
\text { squeling } \\
\text { and } \\
\text { squeling } \\
\text { neath the } \\
\text { knife }\end{array}$ & $\begin{array}{l}\text { Replacing } \\
\text { the image } \\
\text { in the } \mathrm{SL} \\
\text { with a TL } \\
\text { image }\end{array}$ & $\begin{array}{l}{[\ldots], \text { her }} \\
\text { biriniz bir } \\
\text { yıla kalmaz } \\
\text { kesilecek, } \\
\text { kesilirken } \\
\text { çı̆̆lıklar } \\
\text { atarak can } \\
\text { vereceksiniz. }\end{array}$ & $\begin{array}{l}{[\ldots] \text { every single }} \\
\text { of you, a year or } \\
\text { so, will be } \\
\text { slaughtered, } \\
\text { while being } \\
\text { slaughtering you } \\
\text { will die } \\
\text { screaming. }\end{array}$ & $\begin{array}{l}\text { Translating } \\
\text { of } \\
\text { metaphor } \\
\text { by the } \\
\text { equivalent } \\
\text { metaphor }\end{array}$ \\
\hline
\end{tabular}

TT1 Translation Shift: Optional structural shift, class shift, unit shifts, replacement of the symbol, specification, item omission
TT2 Translation Shift: Obligatory structural shift, class shift, unit shift, replacement of the symbol, specification

\begin{tabular}{|l|l|l|l|l|l|l|l|}
\hline $\begin{array}{l}\text { Why, } \\
\text { work } \\
\text { night and } \\
\text { day, body } \\
\text { and soul, } \\
\text { for the } \\
\text { overthrow } \\
\text { of the } \\
\text { human } \\
\text { race! }\end{array}$ & $\begin{array}{l}\text { Original } \\
\text { metaphor }\end{array}$ & $\begin{array}{l}\text { Gece } \\
\text { gündüz, } \\
\text { var } \\
\text { gücümüzle } \\
\text { insan } \\
\text { soyunu alt } \\
\text { etmeye } \\
\text { çalişmalı! }\end{array}$ & $\begin{array}{l}\text { Night and } \\
\text { should } \\
\text { work to } \\
\text { overwhelm } \\
\text { mankind } \\
\text { with all our } \\
\text { strength! }\end{array}$ & $\begin{array}{l}\text { Converting } \\
\text { of } \\
\text { metaphor } \\
\text { to sense }\end{array}$ & $\begin{array}{l}\text { Insan irkını } \\
\text { yok etmek } \\
\text { için } \\
\text { ruhumuzla, } \\
\text { bedenimizle, } \\
\text { gece gündüz } \\
\text { çalışmaliyı! }\end{array}$ & $\begin{array}{l}\text { We must } \\
\text { work } \\
\text { night,day, body } \\
\text { to destroy } \\
\text { the human } \\
\text { race! }\end{array}$ & $\begin{array}{l}\text { Reproducing the } \\
\text { same image in the } \\
\text { TL }\end{array}$ \\
\hline $\begin{array}{l}\text { TT1 Translation Shift: Non-obligatory structural shift, } \\
\text { transferring the sense }\end{array}$ & $\begin{array}{l}\text { TT2 Translation Shift: Non-obligatory structural } \\
\text { shifts, calque }\end{array}$ & \\
\hline
\end{tabular}

\begin{tabular}{|c|c|c|c|c|c|c|c|}
\hline $\begin{array}{l}\text { "Every drop } \\
\text { of it has } \\
\text { gone down } \\
\text { the throats } \\
\text { of our } \\
\text { enemies". }\end{array}$ & $\begin{array}{l}\text { Original } \\
\text { Metapho } \\
r\end{array}$ & $\begin{array}{l}\text { Her bir } \\
\text { damlası } \\
\text { düşmanlarım } \\
\text { 1zın } \\
\text { midesine } \\
\text { indi. }\end{array}$ & $\begin{array}{l}\text { Every drop } \\
\text { (of it) has } \\
\text { gone down } \\
\text { the } \\
\text { stomach of } \\
\text { our } \\
\text { enemies. }\end{array}$ & $\begin{array}{l}\text { Reproducing } \\
\text { the same } \\
\text { image in TL } \\
\text { Partial calque, } \\
\text { replacement of } \\
\text { the symbols }\end{array}$ & $\begin{array}{l}\text { Sütün her } \\
\text { damlası } \\
\text { düşmanları } \\
\text { mızın } \\
\text { boğazından } \\
\text { aşağı indi. }\end{array}$ & $\begin{array}{l}\text { Every drop } \\
\text { of the milk } \\
\text { has gone } \\
\text { down the } \\
\text { throats of } \\
\text { our } \\
\text { enemies. }\end{array}$ & $\begin{array}{l}\text { Specificatio } \\
\text { n, partial } \\
\text { calque of } \\
\text { the } \\
\text { metaphor }\end{array}$ \\
\hline
\end{tabular}

TT1 Translation Shift: Structural shifts, partial calque of the metaphor
TT2 Translation Shift: Structural shifts, partial calque of the metaphor, specification

\section{Discussions and Conclusions}

The study was purposed to analyze the strategies of conveying metaphors from English to Turkish in the political discourse, based on the novel "Animal Farm" by George Orwell and its Turkish translations by Sedat Demir and Celal Üster. It scrutinized recent advancements in the theory and practice of translation, focussing on the tendencies in the translation of political texts, metaphors, and namely problems of translating "Animal Farm" by George Orwell.

Sekret, I. (2020). Strategies of conveying metaphors in political discourse: analysis of the Turkish translations of George Orwell's “Animal Farm”. International Journal of Linguistics, Literature and Culture, 6(4), 103-114. 
The research discussed the problems of translating "Animal Farm" by George Orwell in different languages, studies referring to the metaphor as an instrument of emotive influence on the reader in political discourse.

The study concerned the ways and techniques applied by the Turkish translators to render metaphorical expressions of Old Major's speech from English to Turkish. It was intended to describe the metaphor translation procedures applied by two translators Celal Üster and Sedat Demir with the special focus on the translation shifts and textual deformation that occurred. For the translation notifications and contrasting Celal Üster's translation is marked as TT1 and Sedat Demir's translation as TT2.

In the contrastive analysis of the metaphors in the original text and its two translations, the study was based on Newmark's definition and classification of metaphors. Comparing ST with its translations the attempt was to identify the metaphor, trace how it is conveyed in the TTs, which strategies were applied, and what kind of shifts and deformation occurred in translations.

As the primary objective of this study was to define main tendencies in the Turkish translators' choices about the strategies of conveying metaphors on the example of Old Major's Speech from English into Turkish, in the paper we represented only some expressions to illustrate the revealed regularities.

Analysis of the recent studies and scrutinizing strategies of translating metaphoric units from English into Turkish allowed to define correspondence of the translations to the original texts. To proceed with the conclusions it was important to consider the writing style of the author, which is characterized by the simplicity of the language and forms of the emotional appeal. The impact of the political text (Old Major's Speech as a sample) is mostly realized with the figures, classified as dead and stock metaphors, direct appeals to actions, simplified forms of the sentences. The correspondence of the style of the Turkish translations to the original was considered based on the principles of a) metrical features of the texts, b) presence of the figurative language means, c) equivalence of the force of the emotional impact of the language units upon the audience. Following the mentioned principles allowed to discriminate deformation tendencies that occurred in translations.

Analysis of the data, obtained in the process of contrasting ST and its TT, provided evidence to state that TT1 is characterized by a significant portion of the metrical deformations, ennoblements of the text, which distort the original style, turning it to a more elevated speech. The mentioned features were caused by the multiple cases of using in translation metaphoric units that overcome in their force the emotional impact of the original text, which is characterized by the simplicity of forms and neutrality of the metaphoric units utilized.

Unlike TT1, the translator in TT2 tends to prefer calque in translating the metaphoric units in cases when they cannot be replaced by the TL equivalents or prefers using the translation strategy for transparency of the sentence structure and the lexical units.

Both translators use the strategy of the symbol replacement in transferring the sense of the metaphorical expressions, though TT1 reveals a stronger tendency to use the symbols which are more appealing to the discourse style of the targeted culture. In this sense TT1 significantly overcomes the original text in its emotionality that can be a feature of the Turkish culture communication when it comes to the political discourse and appeals to actions.

Aside from using equivalent metaphoric symbols the translators also apply strategies of grammatical transformations turning the neutrality of the original sentence structure into the emphatic, emotional sentence construction. In this way, the metaphor, existing in the original text, dissolves in the TT, but the message energy becomes compensated by the emphatic sentence structures.

Alongside the remarks laid out as a result of the presented contrastive analysis, the limitations of this study can affect the overall conclusions. Among the limitations are as follows a) the study concerns only the analysis of Old Major's Speech, b) the special focus is on the metaphoric units, though they represent the most prominent features of the political discourse, still it should be remembered that not only metaphors are the tools to provide an emotional impact upon the audience, but also other language means such as sentence structures, repetitions, sound composition, etc. c) the translation strategies and distortions revealed during the analysis can be caused by the special considerations of the translators, those which did not come into the light of this research, therefore, the conclusions, done about the correspondence of the translations to the original text can be also a topic of discussions. 
Conflict of interest statement

The author declared that she has no competing interests.

Statement of authorship

The author has a responsibility for the conception and design of the study. The author has approved the final article.

Acknowledgments

This study was conducted with the support of the Department of Translation and Interpreting of Abant Izzet Baysal University (Bolu, Turkey). Special thanks for the support and consultancy are to the head of the Department Assis. Dr. Huseyin Evcim and English-Turkish translator Gulsen Ay.

Sekret, I. (2020). Strategies of conveying metaphors in political discourse: analysis of the Turkish translations of George Orwell's “Animal Farm”. International Journal of Linguistics, Literature and Culture, 6(4), $103-114$. https://doi.org/10.21744/ijllc.v6n4.911 


\section{References}

Abbasi, A., \& Arjenan, F. M. (2014). Translation of English passive and unaccusative verbs into Farsi: A comparative study of three translations of 'Animal Farm'by Three Iranian Translators. Procedia-Social and Behavioral Sciences, 98, 9-15. https://doi.org/10.1016/j.sbspro.2014.03.382

AL Hasnawi, A. R. (2007). A cognitive approach to translating metaphors.

Askari, M., \& Akbari, A. (2014). Challenges in translation of proper nouns: A case study in Persian translation of George Orwell's Animal Farm. International Journal of Comparative Literature and Translation Studies, 2(2), 19-28.

Ayupova, R. (2014). Pretranslation text analysis as a part of translation process. Procedia-Social and Behavioral Sciences, 136, 213-216. https://doi.org/10.1016/j.sbspro.2014.05.316

Azizmohammadi, F., \& Saadatmanesh, S. (2013). Analysis of Lexical Adjustment in two persian translations of George Orwell's" Nineteen Eighty-Four. Journal of Science and today's world, 2(6), 726-731.

Chesterman, A. (2009). The name and nature of translator studies. HERMES-Journal of Language and Communication in Business, (42), 13-22. https://doi.org/10.7146/hjlcb.v22i42.96844

Conde, T. (2011). Translation evaluation on the surface of texts: a preliminary analysis. The Journal of Specialized Translation, 15, 69-86.

Dam, H. V. (2013). The translator approach in Translation Studies-reflections based on a study of translators' weblogs. 2013). Haasteena näkökulma: Point of View as Challenge. VAKKI Publications, 2, 16-35.

Fadaee, E. (2011). Translation techniques of figures of speech: A case study of George Orwell's" 1984 and Animal Farm. Journal of English and Literature, 2(8), 174-181.

Hayvan çiftliği / George Orwell, (2001) Türkçesi Sedat Demir, by Orwell, George; Demir, Sedat, İstanbul, pp.104, ISBN: 9756841532.

House, J. (2010). Overt and covert translation. Handbook of translation studies, 1, 245-246.

Khorsand, M., \& Salmani, B. (2014). Anthems as Propaganda: A Discoursal Translation Quality Assessment. International Journal of Language Learning and Applied Linguistics World (IJLLALW), 5(3), 222237.

Khorsand, M., \& Salmani, B. (2014). Manipulation of Original Ideology Through Translation: A Discourse-Based Translation Quality Assessment of Speeches. International Journal of Applied Linguistics and English Literature, 3(5), 134-149. http://dx.doi.org/10.7575/aiac.ijalel.v.3n.5p.134

Lakoff, G. (1987). Image Metaphors, in Metaphor and Symbolic Activity 2(3), 219 - 22.

Lakoff, G., \& Johnson, M. (1980). Conceptual metaphor in everyday language. The journal of Philosophy, 77(8), 453-486. https://doi.org/10.2307/2025464

Munday, J. (2016). Introducing translation studies: Theories and applications. Routledge.

Newmark, P. (1988). Approaches to Translation. London: Prentice Hall International (UK) Ltd.

Newmark, P. (1988). A textbook of translation (Vol. 66). New York: Prentice hall.

Orwell, G. (1954/1966). Hayvan Çiftliği [Animal Farm]. (Halide Edib Adıvar,Trans.). Ankara: Milli Egit- im Bakanlıg1 Yayınları.

Orwell, G. (1988). Animal Farm. London: Penguin Books.

Orwell, G. (2011). Hayvan Çiftliği (Bir Peri Masalı) [Animal Farm A Fairy Tale]. (Celal Üster, Trans.) İstanbul: Can Yayınları.

Rad, M. A., \& Razmjou, L. (2013). Translating speech acts in a Persian translation of An English novel. Journal of Educational Research and Studies, 1(5), 50-55.

Shabani, A. (2008). A Comparative Study of the Translation of Image Metaphors of Color in the Shahnameh of Ferdowsi. TranslationDirectory. com.

SparkNotes (Ed.). (2007). SparkNote on Animal Farm. Retrieved $12 \quad 13, \quad 2012 \quad$ from http://www.sparknotes.com/lit/animalfarm/

Strakšienè, M. (2009). Analysis of idiom translation strategies from English into Lithuanian. Kalbu studijos, (14), 13-19.

Taverniers, M. (2002). Metaphor: Handbook of Pragmatics, ed. Jef Verschueren, et al.

Torgny, O. (1997). Metaphor: A working concept. CID.

Volkova, T. A. (2014). Translation model, translation analysis, translation strategy: an integrated methodology.

Yan, C., \& Huang, J. (2014). The culture turn in translation studies. Open Journal of Modern Linguistics, $4(04)$, 487.

Yazic1, M. (2012). Sociological and Political Factors Circumscribing Turkish Version of Animal Farm. The Internet Journal of Language, Culture and Society, 35, 76-81. 